\title{
Study on Consumer Preference and Marketing Strategies of Mango Varieties in Western Zone of Tamil Nadu
}

\author{
M. Kaleeswaran ${ }^{1 *}$, T. Senthivel ${ }^{1}$ and M. Soundarapandian ${ }^{2}$ \\ ${ }^{1}$ School of Agriculture and Animal Sciences, ${ }^{2}$ School of Management studies, Gandhigram \\ Rural Institute- Deemed to be University, Gandhigram, India \\ *Corresponding author
}

A B S T R A C T

\section{Keywords}

Consumer preference, Marketing strategies, Mango varieties

Article Info

Accepted:

17 November 2019

Available Online:

10 December 2019
Mango is one of the most delicious fruit in India and also India is the largest producer of mango in the World. Moreover, Indians are fond of consuming mango fruits and juice especially during summer season. Since the mangoes are grown under various climate regions and its distribution also vary from tropical regions to sub-tropical regions. The marketing of mango fruits and its prices are fluctuating from high to low during the production season. Saratha (2013) reported that the traditional mango fruit marketing channel is long and so many intermediaries like commission agents, wholesalers, retailers are involved. On the other hand consumers ascribed value to its taste, health benefits, seasonal span and socio-cultural importance. Bu keeping the above in view a study was carried out to assess the consumer preference and marketing strategies in mango varieties in two different locations. The results indicated that wholesalers and retailers play a major role in distribution of mangoes to consumers through different channels. Wholesalers and retailers reflected the overall preference towards mango varieties by different consumers. Banaganapalli was the most preferred variety in Udumalpet and Pollachi markets, which was confirmed by the consumers' response. Wholesalers and retailers take decisions based on important factors related to mango varieties viz., price, consumer preference and keeping quality. Wholesalers and retailers purchased mangoes based on the consumers' preference followed by keeping quality and less price in Udumalpet and Pollachi markets, which was also confirmed by the consumers' response. Quality attributes of mangoes like colour, aroma, taste, size and shape were ranked by wholesalers and retailers in both the markets. Taste of the fruits was ranked as first by, while colour and shape of fruit were ranked second and third, size of the fruit in fourth rank and surprisingly, aroma was ranked in fifth place by wholesalers, retailers and consumers in Udumalpet and Pollachi markets. Hence for marketing of mango taste including colour and shape are the deciding qualities to fetch more price in the market. Farmers can choose suitable mango varieties having good taste and colour and shape for cultivation in future. 


\section{Introduction}

Mango denoted as "king of fruit" in India and also the largest producer of mango in the World. Moreover, Indians are fond of consuming mango fruits and juice especially during summer season. Mangoes are cultivated under various climatic conditions to sub-tropical regions. The marketing of mango fruits and its prices are fluctuating from high to low during the production season. After the harvest, the fruits have to pass through several agencies before reaching the consumers at high prices where as the producer farmer who will get only minimum prices. Saratha (2013) reported that the traditional mango fruit marketing channel is long and so many intermediaries like commission agents, wholesalers, retailers are involved. On the other hand consumers ascribed value to its taste, health benefits, seasonal span and sociocultural importance (Badar et al., 2016). Hence in order to obtain more and reasonable profit they have to adopt proper sale of marketing strategies. In India, mango is grown on an area of 2.21 million hectare with annual production 18.51 million tones having productivity of 8.37 metric tons per hectare. By keeping the above in view a study was carried out to assess the consumer preference and marketing strategies in mango varieties in two different locations.

A brief review of literature on Mango marketing and consumer preference is furnished below; Ferrier et al., (2012) reported that Indian mangoes are likely to be confined to a premium niche for U.S. consumers, including South Asians living in the United States who have taste preferences for the Indian varieties. However, cost reductions, through use of sea freight and other efficiencies that may arise from larger volumes of trade, have the potential to make Indian mangoes more cost competitive. Jose and Jose (2012) studied the European Fresh
Mangoes market for Indian Mangoes and reported that it is a highly competitive market, there will be no room for poor quality mangoes. This forces improved efficiency of the production chain and sales strategies resulting from good agricultural practices, increased production and reduced prices that enable competitive prices and better quality products. Sarada (2013) reported the number of players in the marketing channel is more and the mango grower's share in consumer's rupee is less in India. On line spot trading has been introduced by Safal National Exchange (SNX) for Tothapuri mangoes in Krishnagiri district of Tamil Nadu. SNX, by a joint venture between National Diary Development Board and Multi - Commodity Exchange of India (MCX) are carrying out the spot electronic trading of mangoes in Krishnagiri and Pochampalli. Badar et al., (2016) observed that consumers ascribed value to its taste, health benefits, seasonal span and sociocultural importance. The main attributes consumers considered in buying mangoes were price, taste, freshness, and freedom from damage and blemish. Consumers expressed concerns about high mango prices, nonavailability of safely ripened mangoes, retailer malpractices and ineffective regulations by the government. A study by Thulasiram et al., (2016) revealed that the important quality attributes considered by the traders were variety, size, colour, shape and flavor for mango export. The results of conjoint analysis on the average part-worths and the relative importance of each attribute of mango showed variety was found to have the greatest influence on the trade of mango. The size of mango was yet another important factor influencing the traders. The results also showed the quality attributes preferred by the traders of mango are Alphonsa variety, 200$250 \mathrm{~g}$ size and yellow to green colour and ovate oblique shape with high flavour. Saraswat et al., (2018) studied the distribution process and reported that the mango fruit has 
to pass through more than one hand except when it is directly sold to the consumer by the producer which is a rare phenomenon. In this chain, various agencies like grower, preharvest contractors, commission agents, wholesaler, retailers, etc., are engaged. This chain of intermediaries / functionaries is called marketing channel. The followings are the channels generally used by selected organic and inorganic fruit growers: 1. Grower to consumer. 2. Grower - Retailer - Consumer 3. Grower - Preharvest Contractor - Wholesaler - Retailer - Consumer 4. Grower Postharvest Contractor - Wholesaler Retailer - Consumer 5. Grower - Postharvest Contractor - Retailer - Consumer 6. Grower Postharvest Contractor - Wholesaler Retailer - Consumer 7. Grower - Local Wholesaler - Retailer - Consumer 8. Grower - Processor - Consumer. Nandi and Nithya (2018) reported that organic mango farmers are unorganised and prevailing mango value chains vary from long chains where multiple intermediaries involved to very short where farmers directly sell their products to consumers through online. Considering the growing e-commerce retailing trend in fresh products like mango, there is enormous potential for linking smallholder producers to market through organised producer's group in an effective way. Farmer's education, frequent contact with extension staffs, proximity to the market, access to information and collective action in marketing were the main determinants for linking smallholder organic mango farmers to the market. Madhuri (2019) studied the marketing practices of the farmers and observed three predominant marketing channels: at the farm gate to the pre-harvest contractor; at the village Agricultural Produce Market Committee (APMC) yard; or directly in city retail markets or government authorised wholesale centres such as the Horticultural Producers' Cooperative Marketing and Processing Society (HOPCOMS) and Safal. A majority of farmers $(60 \%)$ sell their produce at the farm gate to the pre-harvest contractors, who in most cases are also the wholesale agents at the APMC yard, under a mutually agreed contract. In open market system, mangoes are supposed to be sold on an auction basis here. But this kind of auction system rarely exists. The prices are fixed by wholesale agents operating in the yard, with farmers lacking any power to negotiate them.

\section{Materials and Methods}

Interview schedule was prepared for assessing the consumer preference of different mango varieties with market intermediaries and consumers includes Whole sale merchants, retail merchants and consumers in two locations viz., Udumalpet and Pollachi. The marketing channels and consumer preferences are briefly discussed below: Distribution of mangoes from producers to consumers is an important phenomenon and intermediaries like commission agents, wholesalers and retailers are involved in the marketing channels. For this study, middlemen in Udumulpet and Pollachi blocks were selected and interviewed using a structured questionnaire. Wholesalers (30 from Udumalpet and 40 from Pollachi), retailers (50 from Udumalpet and 60 from Pollachi) and consumers (125 from Udumalpet and 100 from Pollachi) were interviewed on their response on price, consumer preference, keeping quality, colour, aroma, taste, size and shape of three mango varieties viz., Alphonso, Himampasand and Banganapalli. Their responses were coded and analyzed. In this study, Conjoint Analysis was used to find the relative importance of the quality attributes of mango preferred by the consumers. Products possess attributes such as price, color, ingredients, guarantee, environmental impact, predicted reliability, and so on. Consumers typically do not have the option of buying the product that is best in every attribute, particularly when one of those attributes is price. Consumers are forced to 
make trade-offs as they decide which products to purchase. Green and Rao (1971) and Green and Wind (1975) applied conjoint analysis as new technique in decision making and advanced conjoint analysis models were developed by Louviere (1988) and Green and Srinivasan (1990) in the past. Thulasiram et al., (2016) employed conjoint analysis to find out the traders preference for export of mangoes. Conjoint analysis is based on a main effects analysis-of-variance model. Subjects provide data about their preferences for hypothetical products defined by attribute combinations. Conjoint analysis decomposes the judgment data into components, based on qualitative attributes of the products. A numerical part-worth utility value is computed for each level of each attribute. Large partworth utilities are assigned to the most preferred levels, and small part-worth utilities are assigned to the least preferred levels. The attributes with the largest part-worth utility range are considered the most important in predicting preference. Conjoint analysis is a statistical model with an error term and a loss function (Kuhfeld, 2010).

The following 360 samples were taken in two locations (Udumalpet and Pollachi).

\begin{tabular}{|c|c|c|c|}
\hline $\begin{array}{c}\text { Name of } \\
\text { the } \\
\text { Location }\end{array}$ & $\begin{array}{c}\text { Whole sale } \\
\text { merchants }\end{array}$ & $\begin{array}{c}\text { Retail } \\
\text { merchants }\end{array}$ & Consumers \\
\hline Udumalpet & 30 & 50 & 100 \\
\hline Pollachi & 30 & 50 & 100 \\
\hline
\end{tabular}

The above sample beneficiary data were analyzed and results were given below:

\section{Results and Discussion}

The results obtained from the study are furnished here under:

Wholesalers and retailers play a major role in distribution of mangoes to consumers through different channels. Wholesalers and retailers in Udumalpet and Pollachi were interviewed and the results are presented below.

It could be observed from Table 1 that 66.67 per cent of wholesalers ranked Banganapalli as most preferred variety in Udumalpet market and 60 per cent of wholesalers ranked Alphonso in second most preferred followed by Himalpasand by 53.55 per cent of wholesalers. Wholesalers reflect the overall preference of the market by different consumers. Hence, Banaganapalli is the most preferred variety in Udumalpet market.

Varietal preference (by rank) of wholesalers in Pollachi market is presented in Table 1 and it could be inferred that 65 per cent of wholesalers ranked Banganapalli as most preferred variety in Pollachi market and 47.50 per cent of wholesalers ranked Alphonso in second most preferred followed by Himalpasand by 50 per cent of wholesalers. So, Banaganapalli is the most preferred variety in Pollachi market as in case of Udumalpet market (Table 2).

Wholesalers take decisions based on important factors related to mango varieties viz., price, consumer preference and keeping quality. Wholesalers were asked to rank these factors and it is observed from Table 3 that, 86.67 per cent of wholesalers purchase mangoes based on the consumers' preference followed by keeping quality (73.33 per cent) and less price (80 per cent) in Udumalpet market.

It could be observed from Table 4 that 100 per cent of wholesalers in Pollachi ranked taste of the fruit as first, 57.50 per cent of them ranked fruit size as second, 42.50 per cent ranked size and shape as third factor, 52.50 per cent ranked colour as fourth factor and aroma as fifth factor by 85 per cent. These observations are also similar to that of Udumalpet. Taste is most preferred quality 
while aroma is least preferred in both the markets.

Retailers are in direct contact with consumers and their responses reflect the consumers' preference. It could be observed from Table 5 that 54 per cent of retailers ranked Banganapalli as most preferred variety in Udumalpet market and 70 per cent of retailers ranked Alphonso in second most preferred followed by Himalpasand by 60 per cent of retailers.

Like wholesalers, retailers too reflect the overall preference of the market by different consumers. Hence, Banaganapalli is the most preferred variety in Udumalpet market in line with the ranking of wholesalers.
Retailers take decisions to buy mangoes from wholesalers based on important factors related to mango varieties viz., price, consumer preference and keeping quality. Retaiers were asked to rank these factors and it is observed from Table 6 that, 94 per cent of wholesalers purchase mangoes based on the consumers' preference followed by keeping quality ( 80 per cent) and less price ( 84 per cent) in Udumalpet market.

It could be observed from Table 7 that 100 per cent of retailers in Pollachi ranked consumer preference as first, 96.67 per cent of them ranked keeping quality as second and 96.67 per cent ranked less price as third factor to market mango varieties. These observations are similar to that of Udumalpet market as well as that of wholesalers.

Table.1 Ranking of varietal preference of wholesalers in Udumalpet

\begin{tabular}{|l|l|c|c|c|}
\hline S.No. & Rank & Alphonso & Himampasand & Banganapalli \\
\hline $\mathbf{1}$ & I & 7 & 3 & 20 \\
& & $(23.33)$ & $(10.00)$ & $(66.67)$ \\
\hline $\mathbf{2}$ & II & 18 & 11 & 1 \\
& & $(60.00)$ & $(36.67)$ & $(3.33)$ \\
\hline $\mathbf{3}$ & III & 5 & 16 & 9 \\
& & $(16.67)$ & $(53.33)$ & $(30.00)$ \\
\hline & Total & $\mathbf{3 0}$ & $\mathbf{3 0}$ & $\mathbf{3 0}$ \\
& & $\mathbf{( 1 0 0 )}$ & $\mathbf{( 1 0 0 )}$ & $\mathbf{( 1 0 0 )}$ \\
\hline
\end{tabular}

(Figures in parentheses denote percentage to total)

Table.2 Ranking of varietal preference of wholesalers in Pollachi

\begin{tabular}{|l|l|c|c|c|}
\hline S.No. & Rank & Alphonso & Himampasand & Banganapalli \\
\hline $\mathbf{1}$ & I & 8 & 6 & 26 \\
& & $(20.00)$ & $(15.00)$ & $(65.00)$ \\
\hline $\mathbf{2}$ & II & 19 & 14 & 7 \\
& & $(47.50)$ & $(35.00)$ & $(17.50)$ \\
\hline $\mathbf{3}$ & III & 13 & 20 & 7 \\
& & $(32.50)$ & $(50.00)$ & $(17.50)$ \\
\hline & Total & $\mathbf{4 0}$ & $\mathbf{4 0}$ & $\mathbf{4 0}$ \\
& & $\mathbf{( 1 0 0 )}$ & $\mathbf{( 1 0 0 )}$ & $\mathbf{( 1 0 0 )}$ \\
\hline
\end{tabular}

(Figures in parentheses denote percentage to total) 
Table.3 Ranking of major reasons to choose mango varieties by wholesalers in Udumalpet

\begin{tabular}{|l|l|c|c|c|}
\hline S.No. & Rank & Price is less & Consumer preference & Keeping quality \\
\hline $\mathbf{1}$ & I & 2 & 26 & 2 \\
& & $(6.67)$ & $(86.67)$ & $(6.67)$ \\
\hline $\mathbf{2}$ & II & 4 & 4 & 22 \\
& & $(13.33)$ & $(13.33)$ & $(73.33)$ \\
\hline $\mathbf{3}$ & III & 24 & - & 6 \\
& & $(80.00)$ & & $(20.00)$ \\
\hline & Total & $\mathbf{3 0}$ & $\mathbf{3 0}$ & $\mathbf{3 0}$ \\
& & $(\mathbf{1 0 0})$ & $\mathbf{( 1 0 0 )}$ & $\mathbf{( 1 0 0 )}$ \\
\hline
\end{tabular}

(Figures in parentheses denote percentage to total)

Table.4 Ranking of quality attributes of mango varieties by wholesalers in Pollachi

\begin{tabular}{|c|c|c|c|c|c|c|}
\hline S.No. & Rank & Colour & Aroma & Taste & Size & Shape \\
\hline 1 & I & - & - & $\begin{array}{c}40 \\
(100)\end{array}$ & - & - \\
\hline 2 & II & $\begin{array}{c}7 \\
(17.50)\end{array}$ & - & - & $\begin{array}{c}23 \\
(57.50)\end{array}$ & $\begin{array}{c}11 \\
(27.50)\end{array}$ \\
\hline 3 & III & $\begin{array}{c}6 \\
(15.00)\end{array}$ & - & - & $\begin{array}{c}17 \\
(42.50)\end{array}$ & $\begin{array}{c}17 \\
(42.50)\end{array}$ \\
\hline 4 & IV & $\begin{array}{c}21 \\
(52.50)\end{array}$ & $\begin{array}{c}6 \\
(15.00)\end{array}$ & - & - & $\begin{array}{c}13 \\
(32.50)\end{array}$ \\
\hline \multirow[t]{2}{*}{5} & V & $\begin{array}{c}6 \\
(15.00)\end{array}$ & $\begin{array}{c}34 \\
(85.00)\end{array}$ & - & - & - \\
\hline & Total & $\begin{array}{c}40 \\
(100)\end{array}$ & $\begin{array}{c}40 \\
(100)\end{array}$ & $\begin{array}{c}40 \\
(100)\end{array}$ & $\begin{array}{c}40 \\
(100)\end{array}$ & $\begin{array}{c}40 \\
(100)\end{array}$ \\
\hline
\end{tabular}

(Figures in parentheses denote percentage to total)

Table.5 Ranking of varietal preference of retailers in Udumalpet

\begin{tabular}{|l|l|c|c|c|}
\hline S.No. & Rank & Alphonso & Himampasand & Banganapalli \\
\hline $\mathbf{1}$ & I & 10 & 13 & 27 \\
& & $(20.00)$ & $(26.00)$ & $(54.00)$ \\
\hline $\mathbf{2}$ & II & 35 & 7 & 8 \\
& & $(70.00)$ & $(14.00)$ & $(16.00)$ \\
\hline $\mathbf{3}$ & III & 5 & 30 & 15 \\
& & $(10.00)$ & $(60.00)$ & $(30.00)$ \\
\hline & Total & 50 & 50 & 50 \\
& & $(100)$ & $(100)$ & $(100)$ \\
\hline
\end{tabular}

(Figures in parentheses denote percentage to total) 
Table.6 Ranking of major reasons to choose mango varieties by Retailers in Udumalpet

\begin{tabular}{|l|l|c|c|c|}
\hline S.No. & Rank & Price is less & Consumer preference & Keeping quality \\
\hline $\mathbf{1}$ & I & 1 & 47 & 2 \\
\hline $\mathbf{2}$ & II & $(2.00)$ & $(94.00)$ & $(4.00)$ \\
\hline $\mathbf{3}$ & III & $(14.00)$ & 3 & 40 \\
& & 42 & $(6.00)$ & $(80.00)$ \\
\hline & Total & $(84.00)$ & - & 8 \\
& & $\mathbf{5 0}$ & & $(16.00)$ \\
\hline
\end{tabular}

(Figures in parentheses denote percentage to total)

Table.7 Ranking of major reasons to choose mango varieties by Retailers in Pollachi

\begin{tabular}{|l|l|c|c|c|}
\hline S.No. & Rank & Price is less & Consumer preference & Keeping quality \\
\hline $\mathbf{1}$ & I & - & 60 & - \\
\hline $\mathbf{2}$ & II & 2 & $(100.00)$ & 58 \\
& & $(3.33)$ & - & $(96.67)$ \\
\hline $\mathbf{3}$ & III & 58 & - & 2 \\
& & $(96.67)$ & & $(3.33)$ \\
\hline & Total & $\mathbf{6 0}$ & $\mathbf{6 0}$ & $\mathbf{6 0}$ \\
& & $(\mathbf{1 0 0 . 0 0 )}$ & $\mathbf{( 1 0 0 . 0 0 )}$ & $\mathbf{( 1 0 0 . 0 0 )}$ \\
\hline
\end{tabular}

(Figures in parentheses denote percentage to total)

Table.8 Ranking of quality attributes of mango varieties by Retailers in Udumalpet

\begin{tabular}{|l|l|c|c|c|c|c|}
\hline S.No. & Rank & Colour & Aroma & Taste & Size & Shape \\
\hline $\mathbf{1}$ & I & $\begin{array}{c}6 \\
(12.00)\end{array}$ & - & $\begin{array}{c}43 \\
(86.00)\end{array}$ & $\begin{array}{c}1 \\
(2.00)\end{array}$ \\
\hline $\mathbf{2}$ & II & 12 & & 5 & 19 & - \\
& & $(24.00)$ & $(6.00)$ & $(10.00)$ & $(38.00)$ & $(22.00)$ \\
\hline $\mathbf{3}$ & III & 8 & 5 & 1 & 24 & 12 \\
& & $(16.00)$ & $(10.00)$ & $(2.00)$ & $(48.00)$ & $(24.00)$ \\
\hline $\mathbf{4}$ & IV & 14 & 14 & 1 & 6 & 15 \\
& & $(28.00)$ & $(28.00)$ & $(2.00)$ & $(12.00)$ & $(30.00)$ \\
\hline $\mathbf{5}$ & V & 10 & 28 & - & - & 12 \\
& & $(20.00)$ & $(56.00)$ & & & $(24.00)$ \\
\hline & Total & 50 & 50 & 50 & 50 & $50000)$ \\
\hline
\end{tabular}

(Figures in parentheses denote percentage to total) 
Table.9 Ranking of varietal preference of consumers in Udumalpet

\begin{tabular}{|l|l|c|c|c|}
\hline S.No. & Rank & Alphonso & Himampasand & Banganapalli \\
\hline $\mathbf{1}$ & I & 34 & 36 & 55 \\
& & $(27.20)$ & $(28.80)$ & $(44.00)$ \\
\hline $\mathbf{2}$ & II & 71 & 17 & 37 \\
& & $(56.80)$ & $(13.60)$ & $(29.60)$ \\
\hline $\mathbf{3}$ & III & 20 & 72 & 33 \\
& & $(16.00)$ & $(57.60)$ & $(26.40)$ \\
\hline & Total & 125 & 125 & 125 \\
& & $(100)$ & $(100)$ & $(100)$ \\
\hline
\end{tabular}

(Figures in parentheses denote percentage to total)

Table.10 Ranking of major reasons to choose mango varieties by consumers in Pollachi

\begin{tabular}{|l|l|c|c|c|}
\hline S.No. & Rank & Price is less & Consumer preference & Keeping quality \\
\hline $\mathbf{1}$ & I & 11 & 69 & 20 \\
& & $(11.00)$ & $(69.00)$ & $(20.00)$ \\
\hline $\mathbf{2}$ & II & 10 & 13 & 77 \\
& & $(10.00)$ & $(13.00)$ & $(77.00)$ \\
\hline $\mathbf{3}$ & III & 79 & 18 & 3 \\
& & $(79.00)$ & $(18.00)$ & $(3.00)$ \\
\hline & Total & 100 & 100 & 100 \\
& & $(100)$ & $(100)$ & $(100)$ \\
\hline
\end{tabular}

(Figures in parentheses denote percentage to total)

Quality attributes of mangoes like colour, aroma, taste, size and shape were ranked by retailers of Udumalpet market, which are presented in Table 8 . Taste of the fruits was ranked as first by 86 per cent of retailers. Size of the fruit was ranked second by 38 per cent of retailers, while 48 per cent ranked as third. Taste and aroma were ranked together in fourth place by 28 per cent of retailers. In addition, 56 per cent of them ranked aroma as first factor. These responses were also reflecting opinions of wholesalers.

Wholesalers and retailers reflected the overall preference of the market by different consumers, which is confirmed by the results presented in Table 9. It could be observed from the above table that 44 per cent of consumers ranked Banganapalli as most preferred variety in Udumalpet market and
56.80 per cent of consumers ranked Alphonso in second most preferred followed by Himalpasand by 57.60 per cent of consumers. Wholesalers, retailers and consumers reflect the preference of the three mango varieties. Hence, Banaganapalli is the most preferred variety in Udumalpet market.

It could be observed from Table 10 that 69 per cent of consumers in Pollachi ranked their preference as first, 77 per cent of them ranked keeping quality as second and 79 per cent ranked less price as third factor to buy mango varieties. These observations are similar to that of Udumalpet market as well as that of wholesalers and retailers.

The conclusions drawn from this study are furnished below: Wholesalers and retailers play a major role in distribution of mangoes 
to consumers through different channels. Wholesalers and retailers reflected the overall preference towards mango varieties by different consumers. Banaganapalli was the most preferred variety in Udumalpet and Pollachi markets, which was confirmed by the consumers' response. Wholesalers and retailers take decisions based on important factors related to mango varieties viz., price, consumer preference and keeping quality. Wholesalers and retailers purchased mangoes based on the consumers' preference followed by keeping quality and less price in Udumalpet and Pollachi markets, which was also confirmed by the consumers' response. Quality attributes of mangoes like colour, aroma, taste, size and shape were ranked by wholesalers and retailers in both the markets. Taste of the fruits was ranked as first by, while colour and shape of fruit were ranked second and third, size of the fruit in fourth rank and surprisingly, aroma was ranked in fifth place by wholesalers, retailers and consumers in Udumalpet and Pollachi markets. Hence for marketing of mango taste including colour and shape are the deciding qualities to fetch more price in the market. Farmers can choose suitable mango varieties having good taste and colour and shape for cultivation in future.

\section{References}

Badar, H., Ariyawardana, A., and Collins, R. 2016. Mango Value Preferences of Consumers in Pakistan. Acta Horticulturae, (1120)

Ferrier, Peyton, Everett Petersen, and Maurice Landes. 2012. Specialty Crop Access to U.S. Markets: A Case Study of Indian Mangoes, ERR-142, U.S. Department of Agriculture, Economic Research Service, November 2012.

Green P E and Rao V R. 1971.Conjoint measurement for quantifying judgmental data. J. Market. Res. 8: 355-63.

Green P E and Wind Y. 1975.New Way to measure Consumers' Judgements. Harvard Business Review. July-August 75404: 106-117

Green, P.E. and Srinivasan, V. 1990. Conjoint Analysis in Marketing: New Developments with Implications for Research and Practice. Journal of Marketing, 54, 3-19. http://dx.doi.org/10.2307/1251756

José Lincoln Pinheiro Araújo and José Luis Lopez Garcia. 2012. A Study of the Mango Market in the European Union. TECHNICAL-SCIENTIFIC DOCUMENTS. 43 (2): 281-296

Kuhfeld F.W. 2010. Marketing Research Methods in SAS Experimental Design, Choice, Conjoint, and Graphical Techniques. SAS 9.2 Edition MR-2010. Available at https://support.sas.com/techsup/technote/ mr2010.pdf

Louviere, J.J. 1988. Analyzing Decision Making: Metric Conjoint Analysis. Sage University Paper Series on Quantitative Applications in the Social Sciences, 07067. Newbury Park, CA; Sage.

Madhuri Saripalle. 2019. Market Awareness and Profitability: Case Study of Mango Production in Karnataka. Economic and Political Weekly. 54(4).

Sarada Gopalakrishnan. 2013. Marketing System of Mangoes in India. World Applied Sciences Journal. 21(7): 10001007

Thulasiram, R., T. Alagumani and M.R. Duraisamy. 2016. Preferences of quality attributes for mango export: A conjoint analysis approach. International Research Journal of Agricultural Economics and Statistics. 7(1): 42-47 Young, J. S. 1981. Discrete-Trial Choice in Pigeons: Effects of Reinforcer Magnitude. Journal of the Experimental Analysis of Behavior, 35: 23-29. doi:10.1901/jeab.1981.35-23 


\section{How to cite this article:}

Kaleeswaran, M., T. Senthivel and Soundarapandian, M. 2019. Study on Consumer Preference and Marketing Strategies of Mango Varieties in Western Zone of Tamil Nadu. Int.J.Curr.Microbiol.App.Sci. 8(12): 2448-2457. doi: https://doi.org/10.20546/ijcmas.2019.812.288 